\title{
Reoperations Following Cervical Disc Replacement
}

\author{
Branko Skovrli ${ }^{1}$, Dong-Ho Lee ${ }^{2}$, John Michael Caridi ${ }^{1}$, Samuel Kang-Wook Cho ${ }^{3}$ \\ ${ }^{1}$ Department of Neurosurgery, Icahn School of Medicine at Mount Sinai, New York, NY, USA \\ ${ }^{2}$ Department of Orthopaedic Surgery, Asan Medical Center, University of Ulsan College of Medicine, Seoul, Korea \\ ${ }^{3}$ Department of Orthopaedics, Icahn School of Medicine at Mount Sinai, New York, NY, USA
}

\begin{abstract}
Cervical disc replacement (CDR) has emerged as an alternative surgical option to cervical arthrodesis. With increasing numbers of patients and longer follow-ups, complications related to the device and/or aging spine are growing, leaving us with a new challenge in the management and surgical revision of CDR. The purpose of this study is to review the current literature regarding reoperations following CDR and to discuss about the approaches and solutions for the current and future potential complications associated with CDR. The published rates of reoperation (mean, $1.0 \%$; range, $0 \%-3.1 \%$ ), revision (mean, $0.2 \%$; range, $0 \%-0.5 \%$ ), and removal (mean, $1.2 \%$; range, $0 \%-1.9 \%$ ) following CDR are low and comparable to the published rates of reoperation (mean, $1.7 \%$; range; $0 \%-3.4 \%$ ), revision (mean, 1.5\%; range, 0\%-4.7\%), and removal (mean, 2.0\%; range, $0 \%-3.4 \%$ ) following cervical arthrodesis. The surgical interventions following CDR range from the repositioning to explantation followed by fusion or the reimplantation to posterior foraminotomy or fusion. Strict patient selection, careful preoperative radiographic review and surgical planning, as well as surgical technique may reduce adverse events and the need for future intervention. Minimal literature and no guidelines exist for the approaches and techniques in revision and for the removal of implants following CDR. Adherence to strict indications and precise surgical technique may reduce the number of reoperations, revisions, and removals following CDR. Long-term follow-up studies are needed, assessing the implant survivorship and its effect on the revision and removal rates.
\end{abstract}

Keywords: Spine; Cervical vertebra; Intervertebral disc; Arthroplasty; Complications; Reoperations; Options

\section{Introduction}

The current standard of care for patients with cervical spondylotic radiculopathy or myelopathy involving $\leq 3$-levels is anterior cervical discectomy and fusion (ACDF) $[1,2]$. Since its inception over 60 year ago, a multitude of studies have demonstrated the effectiveness of ACDF [1,3]. Although it was shown to have successful outcomes, ACDF relies on the formation of a solid fusion. Results from a meta-analysis based on level 1 data from six Food and Drug Administration (FDA) investigational device exemption (IDE) studies show that ACDF has a
$9.8 \%$ of reoperation rate and $68 \%$ of clinical success rate [4].

Adjacent segment pathology is one important factor that can have negative long-term effects on the clinical results of cervical fusion. In a recent systematic review assessing the risks of adjacent segment pathology, Lawrence et al. [5] found the prevalence of adjacent segment pathology to range from $11 \%-12 \%$ at 5 years, $16 \%-38 \%$ at 10 years, and $33 \%$ at 17 years. They also showed that the mean rate of development for symptomatic degeneration in the cervical spine after arthrodesis is estimated between $1.6 \%-4.2 \%$ per year, and the mean rate of reoperation for

Received Jan 12, 2015; Accepted Jan 12, 2015

Corresponding author: Samuel Kang-Wook Cho

Department of Orthopaedics, Icahn School of Medicine at Mount Sinai,

5 East 98th Street, Box 1188, New York, NY 10029, USA

Tel: +1-212-241-0276, Fax: +1-212-534-5841, E-mail: samuel.cho@mountsinai.org 
Table 1. Indications for cervical disc replacement

\section{Indications for cervical disc replacement}

Symptomatic cervical disc disease at one or two vertebral levels between C3 and T1 confirmed by imaging (MRI, CT or myelogram) showing herniated nucleus pulposus, spondylosis, or loss of disc height of at least $4 \mathrm{~mm}$

Failed $\geq 6$ weeks of conservative management

Between 20 and 70 years of age

No contraindications

$\mathrm{MRI}$, magnetic resonance imaging; CT, computed tomography.

Table 2. Contraindications to cervical disc replacement

Contraindications to cervical disc replacement

$\geq 3$ Vertebral levels requiring treatment

Cervical fusion adjacent to the level to be treated

Cervical instability (translation $>3 \mathrm{~mm}$ and/or $>11$ rotational difference to that or either adjacent level)

Facet joint degeneration

Severe spondylosis (bridging osteophytes, disc height loss $>50 \%$, and absence of motion $<2$ )

Known allergy to implant materials (titanium, polyethylene, cobalt, chromium, and molybdenum

Posttraumatic vertebral body deficiency/deformity

Prior surgery at the treated level

Neck or arm pain of unknown etiology

Axial neck pain as the solitary presenting symptom

Osteoporosis/osteopenia

Active malignancy

Any patient with history of invasive malignancy unless treated and asymptomatic for at least 5 years

Systemic disease (AIDS, HIV, hepatitis B or C, and insulin-dependent diabetes)

Metabolic bone disease (i.e., osteomalacia, osteogenesis imperfect, Padget disease)

Active local/systemic infection

Presently on medications that can interfere with bone/soft tissue healing (i.e., steroids)

Autoimmune spondyloarthropaties (i.e., rheumatoid arthritis)

Pregnant or trying to become pregnant in the next 3 years

AIDS, autoimmune deficiency syndrome; HIV, human immunodeficiency virus.

clinical adjacent level pathology is estimated at $0.8 \%$ per year.

Recently, cervical arthroplasty has emerged as an alternative surgical option to cervical arthrodesis. The theoretical benefits of cervical arthroplasty on adjacent level pathology rely on its motion sparing properties. A number of biomechanical studies suggest that cervical arthroplasty mimics natural cervical motion at the operated level while ACDF does not [6-8]. According to the current standards of care for cervical disc replacement (CDR), it has been estimated that cervical arthroplasty procedures would be performed in $43 \%$ of the patients who require surgery for degenerative pathology of the cervical spine [9]. With increasing number of patients and longer follow-up periods, complications related to the device and/or aging spine may grow, leaving us with a new challenge in the management and surgical intervention of cervical artificial discs.
The lack of literature and no guidelines in the management of failed CDRs makes this an important topic for discussion.

\section{Indications for and Contraindications to CDR}

The main goals of CDR are to avoid fusion of the affected segments, maintain mobility of the involved levels, allow for a speedy return to activity, and eliminate adjacentsegment disease [10]. Indications for CDR include radiculopathy caused by disc herniation, radiculopathy caused by foraminal osteophytes, myelopathy due to a soft disc herniation, and failure of conservative management of single-level disc or spondylosis meeting the appropriate criteria (Table 1) $[9,11]$. Contraindications to cervical total disc replacement (TDR) are summarized in Table 2 [9]. 


\section{Approved CDR Devices}

To date, six CDR devices have been approved by the United States FDA for one-level, and one device has been approved for two-level anterior cervical disc procedures from $\mathrm{C} 3$ to $\mathrm{C} 7$. The three devices initially approved by the FDA include the Bryan Cervical Disc (Medtronic Sofamor Danek, Memphis, TN, USA; approved on May 12, 2009) [12], the Prestige Cervical Disc (Medtronic Sofamor Danek, Memphis, TN, USA; approved on July 16, 2007) [13], and the ProDisc-C (Synthes Spine, West Chester, PA, USA; approved on December 17, 2007) [14]. Since late 2012, three more devices have been approved by FDA which include the Mobi-C Cervical Disc Prosthesis (LDR Spine, Austin, TX, USA; approved on August 7, 2013) [15], the PCM Cervical Disc (NuVasive, San Diego, CA, USA; approved on October 26, 2012) [16], and the Secure-C Disc (Globus Medical, Audubon, PA, USA; approved on September 28, 2012) [17]. Of these six devices, the Bryan cervical disc has the longest reported radiological and clinical follow-ups [10]. On August 23, 2013, Mobi-C Cervical Disc Prosthesis (LDR Spine, Austin, TX) was approved for two-level CDR in adjacent discs from C3 to C7 [18].

\section{Current Experiences with CDR}

In the initial European prospective, multi-centered trial of the Bryan disc evaluating patient's pain, neurological function and range of motion at the implanted level at 6 months and 1 year after implantation showed clinical success rate of $86 \%$ and $90 \%$, respectively [19]. Initial studies comparing the outcomes of cervical arthroplasty versus arthrodesis did not show much difference between the two groups [20-22]. A prospective, multi-centered, randomized control trial for the treatment of persistent radiculopathy or myelopathy, due to single-level cervical disc herniation or spondylosis, showed that at fortyeight months follow up, the Bryan cervical disc group had significantly superior outcomes in neck disability index $(p<0.001)$, neck pain score $(p=0.001)$, arm pain score $(p=0.028)$, and Short Form-36 physical component score $(p=0.007)$ compared with cervical arthrodesis [23]. The latest prospective, multi-centered, randomized, and controlled IDE study evaluating the clinical safety and effectiveness of the Secure-C Disc demonstrated clinically significant improvement in pain and function in terms of neck disability index, visual analog scale, and 36-Item Short Form Health Survey [24].

Although CDR appears to be an acceptable alternative to $\mathrm{ACDF}$, there is currently no strong evidence to support the routine use of CDR over ACDF in single-level cervical spondylosis surgery $[25,26]$.

\section{Adjacent Segment Disease}

To date, studies assessing the incidence of adjacent segment disease, by comparing arthrodesis to arthroplasty, have failed to show any statistically significant reduction in the incidence of adjacent level degeneration between the two groups $[27,28]$. Nunley et al. [28] examined the outcomes at 4 and 7 years for the patients enrolled in five different cervical arthroplasty trials and found a $2.3 \%$ of incidence rate in symptomatic adjacent segment disease. In another study, after a mean follow up of 41.5 months, no difference was found in the rate of additional surgery for symptomatic adjacent segment disease in patients who underwent fusion compared to disc replacement [29]. Sasso et al. [30] compared the outcomes in 242 patients undergoing cervical arthroplasty versus $221 \mathrm{ACDF}$ and found a $4.1 \%$ rate of secondary surgical procedures at adjacent levels, which was same in both groups. A prospective randomized trial by Nunley et al. [31], which assessed the factors affecting the incidence of symptomatic adjacent level disease, found that the risk of developing adjacent segment degeneration was equivalent at median of 38 months after both ACDF and CDR.

\section{Complications}

Surgical approach-related complications were similar between ACDF and CDR. Perioperative complications included wound hematoma, epidural hematoma, superficial or deep wound infection, dysphagia, esophageal or laryngeal injury, thoracic duct injury, angioedema, respiratory insufficiency, vertebral artery, carotid artery or jugular vein laceration, pseudoaneurysm formation, recurrent laryngeal nerve palsy, Horner's syndrome, dural laceration, and cerebrospinal fluid leak (Table 3) [32].

\section{Failures}

Failure of cervical disc arthroplasty was due to a number of factors. Poor patient selection, inadequate preopera- 
Table 3. Complications related to the cervical arthroplasty procedure

\begin{tabular}{|c|c|}
\hline Complications related to the anterior cervical spinal approach & Arthroplasty related complications \\
\hline $\begin{array}{l}\text { Hematoma } \\
\text { Wound } \\
\text { Epidural }\end{array}$ & $\begin{array}{l}\text { Incomplete decompression } \\
\text { Persistent radiculopathy } \\
\text { Persistent myelopathy }\end{array}$ \\
\hline $\begin{array}{l}\text { Wound infection } \\
\text { Superficial } \\
\text { Deep }\end{array}$ & $\begin{array}{l}\text { Malposition } \\
\text { Kyphotic placement } \\
\text { Off-center }\end{array}$ \\
\hline Esophageal injury & Heterotopic ossification/fusion \\
\hline Laryngeal injury & Improper sizing of implant \\
\hline Dysphagia & Bearing surface wear \\
\hline Recurrent laryngeal nerve palsy & Metallosis \\
\hline Thoracic duct injury & Subsidence \\
\hline Angioedema & Vertebral body fracture \\
\hline Respiratory insufficiency & Vertebral body osteolysis \\
\hline Pseudo-aneurysm formation & Infection of implant \\
\hline $\begin{array}{l}\text { Vascular injury } \\
\text { Carotid artery } \\
\text { Vertebral artery } \\
\text { Jugular vein }\end{array}$ & Neurologic injury \\
\hline \multicolumn{2}{|l|}{ Horner syndrome } \\
\hline \multicolumn{2}{|l|}{ Dural laceration } \\
\hline Cerebrospinal fluid leak & \\
\hline
\end{tabular}

tive planning, suboptimal surgical technique, and malpositioning of the device accounted for the majority of the implant failures, with mechanical implant failure and biologic and chemical failure defining the remainder (Fig. 1). Although many of the complications that were experienced in cervical arthroplasty were also seen in cervical arthrodesis procedures (Table 3) [32], there were specific complications related to CDR (Tables 3, 4) [22,27,32-53].

\section{Rates of Reoperation, Revision and Removal}

Surgical interventions following CDR and ACDF can be divided into reoperations, revisions, and removals. The FDA defines a reoperation as any procedure at the target level that does not remove, modify, or add any original implant component [54]. In the case of CDR and ACDF, reoperation includes laminoforaminotomy, laminectomy, and/or posterior fusion. The FDA defines revision surgery as a procedure that adjusts or modifies, in any way, the original implant configuration [54]. The FDA defines removal surgery as a procedure that removes one or more components of the original implant replacing it with a different type of implant [54]. An additional surgical intervention in ACDF is supplemental fixation, which is performed in the cases of pseudarthrosis.

\section{CDR}

Surgical intervention rates following CDR have been reported in the FDA IDE studies as well as in several larger series published in the literature. From a total of 1,068 cervical arthroplasty levels operated with a mean followup of 2.3 years (range, 2-4 years), we established the mean rate of reoperation at $1.0 \%$ (range, $0 \%-3.1 \%$ ), revision at $0.2 \%$ (range, $0 \%-0.5 \%$ ), and removal at $1.2 \%$ (range, 0\%-1.9\%) (Table 5) [22,23,30,35,36,38,44,55].

\section{ACDF}

Studies comparing CDR versus ACDF were used to calculate the surgical intervention rates following ACDF. From a total of 744 ACDF levels operated with a mean follow-up of 3.2 years (range, 2-4 years), we established the mean rate of reoperation at $1.7 \%$ (range, $0 \%-3.4 \%$ ), 
revision at $1.5 \%$ (range, $0 \%-4.7 \%$ ), removal at $2.0 \%$ (range, $0 \%-3.4 \%$ ), and supplemental fixation at $2.4 \%$ (range, $0 \%-3.4 \%)[23,30,35,36,55,56]$.

\section{Discussion}

\section{Options for failed CDR}

The options for surgical intervention depend on the nature of the complication and on radiographic and clinical picture of the patient. In the cases of infection with extrusion, gross malposition, subsidence, or retropulsion, the most suitable option is explantation of the device followed by fusion. Similar to most implants, explantation can result in the removal of excessive bone in one or both ver- tebral bodies. In those circumstances, the amount of bone removed will dictate the need for a single or double level corpectomy; and in extreme cases where an anterior plate cannot fit, a cage followed by a posterior instrumented fusion is necessary. In patients who are symptomatic from malalignment or subsidence but lack neurologic symptoms, a posterior instrumented fusion alone is a viable option. Yet, another theoretical option, in the cases of frank device malfunction and even malalignment, is the removal of the device followed by reimplantation with a new implant. In patients with radicular symptoms following arthroplasty, who are found to have foraminal stenosis or a foraminal disc herniation, simple posterior foraminotomy can be the procedure of choice. In the cases where the radicular symptoms arise from a more centrally
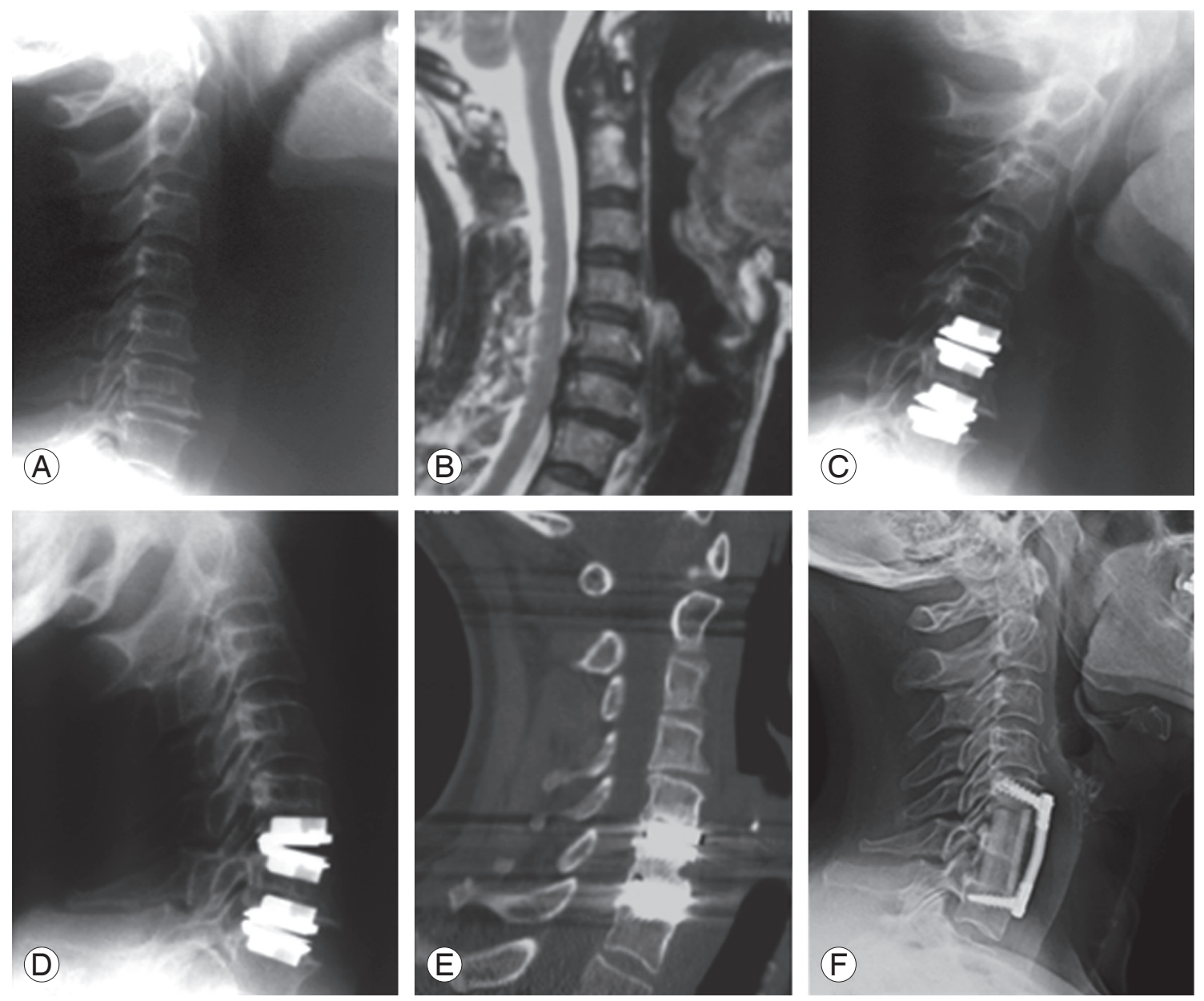

Fig. 1. A 56-year-old female presented with cervical radiculopathy. Radiographic studies showed C5/6 and C6/7 disc herniations with advanced spondylosis (A, B). She underwent 2-level cervical disc replacement (CDR) with resolution of radiculopathy. Several months later, the patient developed severe axial neck pain. Radiographs demonstrated proper placement of CDRs (C, D) with lucency around the superior aspect of the C5/6 CDR (E). The patient eventually underwent a one-level corpectomy (F), with complete resolution of axial neck pain. This case demonstrates poor patient selection, as advanced spondylosis is a contraindication to CDR. 
Table 4. Arthroplasty specific complications

\begin{tabular}{|c|c|c|c|c|}
\hline $\begin{array}{l}\text { Specific } \\
\text { complication }\end{array}$ & Author & Procedure, \#study & Implant & Findings \\
\hline Dysphagia & $\begin{array}{l}\text { Anderson et al. } \\
\text { [33] } \\
\text { McAfee et al. [34] }\end{array}$ & $\begin{array}{l}242 \text { TDR:221 ACDF } \\
151 \text { TDR:100 ACDF }\end{array}$ & $\begin{array}{l}\text { Bryan } \\
\text { Porous coated } \\
\text { Motion TDR }\end{array}$ & $\begin{array}{l}\text { Bryan increased incidence of dysphagia/ } \\
\text { dysphonia ( } 26 \text { vs. 16) } \\
\text { Less incidence of dysphagia in PCM }(p<0.05)\end{array}$ \\
\hline $\begin{array}{l}\text { Persistent } \\
\text { radiculopathy }\end{array}$ & $\begin{array}{l}\text { US FDA IDE } \\
\text { studies }[22,35,36] \\
\text { Anderson and } \\
\text { Rouleau [37] }\end{array}$ & $\begin{array}{l}276 \text { TDR:265 ACDF } \\
103 \text { TDR:105 ACDF } \\
242 \text { TDR:221 ACDF } \\
\text { Review of literature }\end{array}$ & $\begin{array}{l}\text { Prestige } \\
\text { ProDisc-C } \\
\text { Bryan } \\
\text { Bryan }\end{array}$ & $\begin{array}{l}1.4 \% \\
1.9 \% \\
2.5 \% \\
\text { Complications from inadequate decompression } \\
\text { present in } 7 \text { of } 11 \text { failures (63.6\%) }\end{array}$ \\
\hline $\begin{array}{l}\text { Kyphosis } \\
\text { Graft }\end{array}$ & Pickett et al. [38] & 96 TDR & Bryan & $\begin{array}{l}\text { Kyphotic implant alignment in } 2 \text { out of } 74 \\
\text { patients }\end{array}$ \\
\hline $\begin{array}{l}\text { Functional } \\
\text { spinal unit } \\
\text { (FSU) }\end{array}$ & $\begin{array}{l}\text { Sekhon [39] } \\
\text { Pickett et al. [40] } \\
\text { Johnson et al. [41] }\end{array}$ & $\begin{array}{l}11 \mathrm{TDR} \\
14 \mathrm{TDR}\end{array}$ & $\begin{array}{l}\text { Bryan } \\
\text { Bryan }\end{array}$ & $\begin{array}{l}3 \text { of } 11 \text { patients with worsening kyphosis } \\
\text { Shell endplate angle mean change }-3.8^{\circ} \\
(p=0.004) \\
\text { FSU angle mean change }-6^{\circ}(p=0.001) \\
\text { Mean segmental loss of } 4.7^{\circ} \text { at operated level }\end{array}$ \\
\hline Malposition & Anderson et al. [33] & 242 TDR:221 ACDF & Bryan & $\begin{array}{l}\text { Implant malposition needing revision in } 1 \text { of } \\
242\end{array}$ \\
\hline $\begin{array}{l}\text { Heterotopic } \\
\text { ossification } \\
\text { (HO) }\end{array}$ & $\begin{array}{l}\text { Leung et al. [42] } \\
\text { Yi et al. [51] } \\
\text { Chen et al. [43] }\end{array}$ & $\begin{array}{l}90 \text { TDR } \\
170 \text { TDR } \\
509 \text { TDR }\end{array}$ & $\begin{array}{l}\text { Bryan } \\
\text { Bryan, Mobi-C, } \\
\text { ProDisc-C } \\
\text { Bryan, Mobi-C, } \\
\text { ProDisc-C, M6-C }\end{array}$ & $\begin{array}{l}\text { HO developed in } 16 \text { of } 90 \text { patients (17.8\%) } \\
\text { Overall rate of } \mathrm{HO} 40.6 \%(69 / 170) \\
21.0 \% \text { Bryan, } 52.5 \% \text { Mobi-C, } 71.4 \% \text { ProDisc-C } \\
\text { Pooled prevalence } \mathrm{HO} \text { was } 44.6 \% \text { at } 12 \mathrm{mo} \text {, } \\
58.2 \% \text { at } 24 \mathrm{~m} \text {. } \\
\text { Advanced } \mathrm{HO} 11.1 \% \text { and } 16.7 \% \text { at } 12 \mathrm{mo} \text { and } \\
24 \text { mo, respectively }\end{array}$ \\
\hline $\begin{array}{l}\text { Improper sizing } \\
\text { Device too } \\
\text { small } \\
\text { Device too } \\
\text { large }\end{array}$ & $\begin{array}{l}\text { Womack et al. [52] } \\
\text { Goffin et al. [44] } \\
\text { Buchowski et al. } \\
\text { [50] }\end{array}$ & $\begin{array}{l}\text { Investigational study } \\
146 \text { TDR } \\
\text { Journal article }\end{array}$ & $\begin{array}{l}\text { ProDisc-C } \\
\text { Bryan } \\
\text { Bryan }\end{array}$ & $\begin{array}{l}\downarrow \text { Surface area leads to } \uparrow \text { loading and acceler } \\
\text { ated wear } \\
\text { Implant migration in } 3 \text { of } 146 \text { patients ( } 2.1 \% \text { ) } \\
\text { Stretching of facet joints leading to pain and } \\
\text { decreased ROM }\end{array}$ \\
\hline $\begin{array}{l}\text { Bearing surface } \\
\text { wear }\end{array}$ & $\begin{array}{l}\text { Cavanaugh et al. } \\
\text { [45] } \\
\text { Guyer et al. [46] }\end{array}$ & $\begin{array}{l}\text { Case Report } \\
\text { Case Report }\end{array}$ & $\begin{array}{l}\text { "Keel"-based implant } \\
\text { Kineflex-C }\end{array}$ & $\begin{array}{l}\text { Delayed hyper-activity to cobalt-chromium- } \\
\text { molybdenum alloy metal-on-metal device } \\
\text { Lymphocytic reaction leading to early failure of } \\
\text { implant }\end{array}$ \\
\hline Subsidence & Gornet [53] & 551 TDR & Prestige, ProDisc-C & $\begin{array}{l}\text { Subsidence in 9/551 (1.6\%), angular } \\
\text { subsidence concern in "keel" based implants }\end{array}$ \\
\hline $\begin{array}{l}\text { Vertebral body } \\
\text { fracture }\end{array}$ & $\begin{array}{l}\text { Shim et al. [47] } \\
\text { Datta et al. [48] } \\
\text { Jawahar et al. [27] }\end{array}$ & $\begin{array}{l}\text { Case Report } \\
\text { Case Report } \\
\text { Case Report }\end{array}$ & $\begin{array}{l}\text { ProDisc-C } \\
\text { ProDisc-C } \\
\text { ProDisc-C }\end{array}$ & $\begin{array}{l}\text { Posterior avulsion fractures of } \mathrm{C} 6 \text { and } \mathrm{C} 7 \\
\text { C6 vertebral body sagittal split fracture } \\
\text { C5 vertebral body coronal fracture }\end{array}$ \\
\hline Osteolysis & $\begin{array}{l}\text { Tumialan and Gluf } \\
\text { [49] }\end{array}$ & Case Report & ProDisc-C & Progressive osteolysis of C6 vertebral body \\
\hline Infection & $\begin{array}{l}\text { Anderson et al. } \\
\text { [33] } \\
\text { Anderson and } \\
\text { Rouleau [37] }\end{array}$ & 242 TDR:221 ACDF & Bryan & $\begin{array}{l}\text { Superficial wound infection in } 7 \text { of } 242 \text { (1 of } \\
221 \text { in control group) requiring antibiotic } \\
\text { treatment } \\
\text { Reported } 0.13 \% \text { explantation rate due to } \\
\text { infection }\end{array}$ \\
\hline
\end{tabular}

TDR, total disc replacement; ACDF, anterior cervical discectomy and fusion; PCM, porous-coated motion; FDA IDE, Food and Drug Administration investigational device exemption; ROM, range of motion. 
Table 5. Secondary intervention rates at the target level in cervical disc replacement

$\begin{array}{llllccc}\text { Author } & \begin{array}{c}\text { Year of } \\ \text { publication }\end{array} & \text { Study, duration } & \begin{array}{c}\text { Implant } \\ \text { type }\end{array} & \begin{array}{c}\text { Total } \\ \text { implanted } \\ \text { levels }\end{array} & \begin{array}{c}\text { Secondary } \\ \text { intervention } \\ \text { rate (\%) }\end{array} & \begin{array}{c}\text { Revision } \\ \text { rate (\%) }\end{array} \\ \text { Roffin et al. [44] } & 2003 & \text { Prospective, MCT } & \text { Bryan } & 189 & 1.6 & 0.5 \\ \text { rate (\%) }\end{array}$

MCT, multi-center trial; MCS, multi-center study; RCCT, randomized control clinical trial; FDA IDE, Food and Drug Administration investigational device exemption; PRCT, prospective randomized control trial.

Table 6. Current reports of procedures performed for revision cervical disc replacement

\begin{tabular}{|c|c|c|c|c|}
\hline Author & Study design & Implant & Complication & Revision procedure \\
\hline Goffin et al. [19] & PMCT (n=143, R=1.5\%) & $\begin{array}{l}\text { Bryan } \\
\text { Bryan } \\
\text { Bryan }\end{array}$ & $\begin{array}{l}\text { Persistent myelopathy } \\
\text { Persistent radiculopathy } \\
\text { Persistent radiculopathy }\end{array}$ & $\begin{array}{l}\text { Posterior laminectomy } \\
\text { Posterior foraminotomy } \\
\text { Anterior decompression, } \\
\text { implant repositioning }\end{array}$ \\
\hline Sasso et al. [23] & PRCT ( $n=242, R=3.7 \%)$ & Bryan & Persistent neck/shoulder pain & ACDF \\
\hline Buchowski et al. [50] & Review of literature & Bryan & Infection & ACDF \\
\hline Anderson et al. [33] & $\operatorname{RCS}(n=242, R=2.9 \%)$ & Bryan & Device malposition & Repositioning of implant \\
\hline Pickett et al. [38] & PCT ( $n=74, R=5.4 \%)$ & $\begin{array}{l}\text { Bryan } \\
\text { Bryan }\end{array}$ & $\begin{array}{l}\text { Segmental kyphosis } \\
\text { Persistent radiculopathy }\end{array}$ & $\begin{array}{l}\text { ACDF } \\
\text { Posterior foraminotomy }\end{array}$ \\
\hline Cavanaugh et al. [45] & Case report & Keel-based & Hyper-reactivity to metallosis & ACDF \\
\hline Tumialan and Gluf [49] & Case report & ProDisc-C & Vertebral body osteolysis & ACDF \\
\hline Guyer et al. [46] & Case report & Kineflex-C & Lymphocytic reaction & ACDF \\
\hline Fan et al. [57] & Case report & Bryan & Device malfunction & ACDF \\
\hline Nguyen et al. [58] & Case report & Ceramic-on-ceramic & Device malfunction & ACDF \\
\hline Chen et al. [59] & Case report & Bryan & Neurologic injury & Anterior corpectomy, fusion \\
\hline
\end{tabular}

CDR, cervical disc replacement; PMCT, prospective multi-center trial; R: revision rate; PRCT, prospective randomized control trial PCT; ACDF, anterior cervical discectomy and fusion; RCS, randomized control study; PCT, prospective clinical trial.

located lesion or in the cases of myelopathy from spinal canal stenosis, the options are removal of the device and thorough decompression followed by either an anterior fusion or reimplantation of the same arthroplasty device or a brand new one.

\section{Current reports of procedures performed in failed CDR (Table 6)}

In all reported surgical interventions following cervical arthroplasty, in which the implant needed replacement for reasons related to device malfunction, vertebral body osteolysis, infection, segmental kyphosis, lymphocytic reaction, or hyper-reactivity to metallosis, the surgeons chose to remove the implant and performed an arthrodesis $[38,45,46,49,50,57,58]$. In the cases of vertebral body or end-plate fracture during the initial surgery, removal of fragments and careful evaluation of the stability of the fracture followed by implantation of the artificial disc prosthesis was performed $[47,48]$. There were no reports 
of vertebral fracture during initial placement of the prosthesis, requiring corpectomy and/or fusion for stabilization. In a case of a fracture identified on postoperative imaging, evaluation of stability and close radiographic follow-up until the fracture healed was reported [24]. One reported case of prosthesis malposition required reoperation for proper repositioning of the device [33]. In the cases of persistent radiculopathy following cervical disc arthroplasty, posterior foraminotomy at the affected level was the procedure of choice $[38,50]$. For the cases of neurologic injury following CDR, implant removal was performed followed by corpectomy and thorough spinal cord decompression and fusion [59]. One report of persistent myelopathy following CDR was treated with posterior laminectomy for spinal cord decompression [26]. In a case of persistent neck and shoulder pain, implant removal and conversion to arthrodesis was performed [23].

\section{Intraoperative approaches in CDR interventions}

Removal of the arthroplasty device itself can present a multitude of challenges. There is no consensus in the literature on the techniques for removal of the artificial discs from the cervical spine. In the Synthes ProDisc-C Removal Technique Guide Manual [60], the recommendations are removal of the implant by disassembly of the components. The manufacturer recommends approaching the operative level through the original anterior incision followed by careful removal of scar tissue and osteophytes to expose the implant-bone junction. The implant removal should be done under distraction. Anterior cortices should be perforated using an awl, followed by removal of the polyethylene inlay using inlay separators. Forked or straight osteotomes should be used for the separation of the metal endplates from the vertebral bodies. All components are to be pulled out using a Kocher style forceps. In the Medtronic Bryan Surgical Technique manual, the manufacturer recommends using a chisel or osteotome to free the implant from the vertebral endplates after the disc space has been distracted [61]. There is no published guideline for removal of the Prestige cervical disc system.

Currently, there is a lack of literature on removal of previously implanted arthroplasty devices as well as on individual surgeon's experiences and techniques, used in complicated extractions of cervical artificial discs.

\section{Potential future problems with CDR}

There are several concerns associated with CDR that have not been addressed clinically due to the relative novelty of this technology. Implant survivorship in patients is one major concern. Subsequent development and management of adjacent level pathology is another. Do we implant more CDRs or convert to fusion? If we choose ACDF, what do we do with the device that is already implanted in the patient? Thirdly, the aging spine with deterioration of bone quality in the presence of these artificial devices could pose a challenge during extraction and subsequent stabilization procedures.

Motion preservation is the cornerstone of the cervical total disc replacement procedure. As such, the best candidates for motion preservation are young patients with good baseline segmental motion [12]. The bulk of the literature regarding artificial joint longevity comes from the orthopaedic literature of prosthetic hip and knee implants. The average age for the patients undergoing total knee and hip replacement is 68 and 67 years [62], respectively; while in one study assessing the sagittal cervical alignment following arthrodesis and arthroplasty surgery in 180 patients, the average age was 42.2 and 41.7 , respectively [63]. A retrospective analysis of 11,606 primary total knee arthroplasties showed prosthesis survivorship of $91 \%$ at ten years, $84 \%$ at fifteen years, and $78 \%$ at twenty years following surgery [64]. Compared to the older and less active population with artificial knee and hip, the younger group with cervical disc replacement may experience greater prosthetic wear. If the numbers from the literature on artificial hip and knee can be translated into the cervical artificial disc longevity, the vast majority of patients who undergo CDR will need a surgical intervention at least once in their lifetime.

The only published study, investigating on the very late complications of CDR, evaluated complications occurring more than 4 years after the index surgical procedures in the FDA IDE trials of Bryan and Prestige discs [65]. Out of the 94 patients, $4.3 \%$ showed evidence of bone loss in peridevice vertebral body, $1.1 \%$ experienced posterior device migration, and 3.2\% necessitated revision surgery. The authors concluded that similar to large-joint arthroplasty, delayed device-related complications may occur in CDR and that these complications commence well beyond the time frame for complications associated with more traditional cervical spine procedures. 


\section{Conclusions}

Reported rates of surgical interventions following failed CDR are low (mean, $2.4 \%$; range, $0 \%-4.1 \%$ ). The majority of these complications are related to poor patient selection and surgical techniques. However, a small percentage is also attributed to the device failure itself. With the growing number of patients receiving CDR, awareness needs to be established regarding the future need for surgical intervention as well as guidelines for approaches and techniques to minimize risks during reoperation, revision, and removal surgery.

\section{Conflict of Interest}

No potential conflict of interest relevant to this article was reported.

\section{References}

1. Bohlman HH, Emery SE, Goodfellow DB, Jones PK. Robinson anterior cervical discectomy and arthrodesis for cervical radiculopathy: long-term follow-up of one hundred and twenty-two patients. J Bone Joint Surg Am 1993;75:1298-307.

2. Goffin J, Geusens E, Vantomme N, et al. Long-term follow-up after interbody fusion of the cervical spine. J Spinal Disord Tech 2004;17:79-85.

3. Palit M, Schofferman J, Goldthwaite N, et al. Anterior discectomy and fusion for the management of neck pain. Spine (Phila Pa 1976) 1999;24:2224-8.

4. Pettine KA, Eiserman L. Meta-analysis of class I results of anterior cervical decompression and fusion with allograft and plating. In: American Academy of Orthopaedic Surgeons. 2012 Annual Meeting; 2012 Feb 7-11; San Franciso, CA, USA.

5. Lawrence BD, Hilibrand AS, Brodt ED, Dettori JR, Brodke DS. Predicting the risk of adjacent segment pathology in the cervical spine: a systematic review. Spine (Phila Pa 1976) 2012;37:S52-64.

6. DiAngelo DJ, Roberston JT, Metcalf NH, McVay BJ, Davis RC. Biomechanical testing of an artificial cervical joint and an anterior cervical plate. J Spinal Disord Tech 2003;16:314-23.

7. Dmitriev AE, Cunningham BW, Hu N, Sell G, Vigna F, McAfee PC. Adjacent level intradiscal pressure and segmental kinematics following a cervical total disc arthroplasty: an in vitro human cadaveric model.
Spine (Phila Pa 1976) 2005;30:1165-72.

8. Puttlitz CM, Rousseau MA, Xu Z, Hu S, Tay BK, Lotz JC. Intervertebral disc replacement maintains cervical spine kinetics. Spine (Phila Pa 1976) 2004;29:280914.

9. Auerbach JD, Jones KJ, Fras CI, Balderston JR, Rushton SA, Chin KR. The prevalence of indications and contraindications to cervical total disc replacement. Spine J 2008;8:711-6.

10. Cao JM, Zhang YZ, Shen Y, Ding WY. Complications of Bryan cervical disc replacement. Orthop Surg 2010;2:86-93.

11. Moatz B, Tortolani PJ. Cervical disc arthroplasty: pros and cons. Surg Neurol Int 2012;3:S216-24.

12. US Food and Drug Administration. BRYAN ${ }^{\circledR}$ Cervical Disc-P060023 [Internet]. Silver Spring: US Food and Drug Administration; 2012 [cited 2015 Apr 21]. Available from: http://www.fda.gov/MedicalDevices/ProductsandMedicalProcedures/DeviceApprovalsandClearances/Recently-ApprovedDevices/ ucm162968.htm.

13. US Food and Drug Administration. PRESTIGE ${ }^{\circledR}$ Cervical Disc System-P060018 [Internet]. Silver Spring: US Food and Drug Administration; 2013 [cited 2015 Apr 21]. Available from: http://www.fda.gov/MedicalDevices/ProductsandMedicalProcedures/DeviceApprovalsandClearances/Recently-ApprovedDevices/ucm076928.htm.

14. US Food and Drug Administration. ProDisc ${ }^{\mathrm{m}}-\mathrm{C}$ Total Disc Replacement-P070001 [Internet]. Silver Spring: US Food and Drug Administration; 2013 [cited 2015 Apr 21]. Available from: http://www. fda.gov/MedicalDevices/ProductsandMedicalProcedures/DeviceApprovalsandClearances/RecentlyApprovedDevices/ucm074813.htm.

15. US Food and Drug Administration. Mobi-C Cervical Disc Prosthesis-P110002 [Internet]. Silver Spring: US Food and Drug Administration; 2013 [cited 2015 Apr 21]. Available from: http://www.fda.gov/MedicalDevices/ProductsandMedicalProcedures/DeviceApprovalsandClearances/Recently-ApprovedDevices/ucm366047.htm.

16. US Food and Drug Administration. PCM Cervical Disc System-P100012 [Internet]. Silver Spring: US Food and Drug Administration; 2012 [cited 2015 Apr 21]. Available from: http://www.fda.gov/MedicalDevices/ProductsandMedicalProcedures/DeviceAp- 
provalsandClearances/Recently-ApprovedDevices/ ucm327487.htm.

17. US Food and Drug Administration. Secure-C Artificial Cervical Disc-P100003 [Internet]. Silver Spring: US Food and Drug Administration; 2012 [cited 2015 Apr 21]. Available from: http://www.fda.gov/MedicalDevices/ProductsandMedicalProcedures/DeviceApprovalsandClearances/Recently-ApprovedDevices/ucm322270.htm.

18. US Food and Drug Administration. Mobi-C Cervical Disc Prosthesis (two-level)-P110009 [Internet]. Silver Spring: US Food and Drug Administration; 2013 [cited 2015 Apr 21]. Available from: http://www. fda.gov/MedicalDevices/ProductsandMedicalProcedures/DeviceApprovalsandClearances/RecentlyApprovedDevices/ucm367809.htm.

19. Goffin J, Casey A, Kehr P, et al. Preliminary clinical experience with the Bryan Cervical Disc Prosthesis. Neurosurgery 2002;51:840-5.

20. Coric D, Nunley PD, Guyer RD, et al. Prospective, randomized, multicenter study of cervical arthroplasty: 269 patients from the Kineflex|C artificial disc investigational device exemption study with a minimum 2-year follow-up: clinical article. J Neurosurg Spine 2011;15:348-58.

21. Goffin J. Complications of cervical disc arthroplasty. Semin Spine Surg 2006;18:87-98.

22. Heller JG, Sasso RC, Papadopoulos SM, et al. Comparison of BRYAN cervical disc arthroplasty with anterior cervical decompression and fusion: clinical and radiographic results of a randomized, controlled, clinical trial. Spine (Phila Pa 1976) 2009;34:101-7.

23. Sasso RC, Anderson PA, Riew KD, Heller JG. Results of cervical arthroplasty compared with anterior discectomy and fusion: four-year clinical outcomes in a prospective, randomized controlled trial. J Bone Joint Surg Am 2011;93:1684-92.

24. Vaccaro A, Beutler W, Peppelman W, et al. Clinical outcomes with selectively constrained SECURE-C cervical disc arthroplasty: two-year results from a prospective, randomized, controlled, multicenter investigational device exemption study. Spine (Phila Pa 1976) 2013;38:2227-39.

25. Fallah A, Akl EA, Ebrahim S, et al. Anterior cervical discectomy with arthroplasty versus arthrodesis for single-level cervical spondylosis: a systematic review and meta-analysis. PLoS One 2012;7:e43407.
26. Zechmeister I, Winkler R, Mad P. Artificial total disc replacement versus fusion for the cervical spine: a systematic review. Eur Spine J 2011;20:177-84.

27. Jawahar A, Cavanaugh DA, Kerr EJ 3rd, Birdsong EM, Nunley PD. Total disc arthroplasty does not affect the incidence of adjacent segment degeneration in cervical spine: results of 93 patients in three prospective randomized clinical trials. Spine J 2010; 10:1043-8

28. Nunley PD, Coric D, Jawahar A, et al. Total disc replacement in cervical spine: 4-7 years follow-up for primary outcomes and symptomatic adjacent segment disease [Internet]. Rosemont: Cervical Spine Research Society; 2011 [cited 2015 Apr 21]. Available from: http://www.csrs.org/total-disc-replacement-incervical-spine-47-years-follow-up-for-primary-outcomes-and-symptomatic-adjacent-segment-disease/.

29. Murrey DB, Ziegler JE, Goldstein JA, et al. Five-year results of the ProDisc-C Multi-Center Randomized Clinical Trial. Proceedings of the Cervical Spine Research Society 39th Annual Meeting; 2011 Dec 9; Scottsdale, AZ, USA.

30. Sasso RC, Smucker JD, Hacker RJ, Heller JG. Clinical outcomes of BRYAN cervical disc arthroplasty: a prospective, randomized, controlled, multicenter trial with 24-month follow-up. J Spinal Disord Tech 2007;20:481-91.

31. Nunley PD, Jawahar A, Kerr EJ 3rd, et al. Factors affecting the incidence of symptomatic adjacent-level disease in cervical spine after total disc arthroplasty: 2- to 4-year follow-up of 3 prospective randomized trials. Spine (Phila Pa 1976) 2012;37:445-51.

32. Graham JJ. Complications of cervical spine surgery: a five-year report on a survey of the membership of the Cervical Spine Research Society by the Morbidity and Mortality Committee. Spine (Phila Pa 1976) 1989;14: 1046-50.

33. Anderson PA, Sasso RC, Riew KD. Comparison of adverse events between the Bryan artificial cervical disc and anterior cervical arthrodesis. Spine (Phila Pa 1976) 2008;33:1305-12.

34. McAfee PC, Cappuccino A, Cunningham BW, et al. Lower incidence of dysphagia with cervical arthroplasty compared with ACDF in a prospective randomized clinical trial. J Spinal Disord Tech 2010;23: 1-8.

35. Murrey D, Janssen M, Delamarter R, et al. Results of 
the prospective, randomized, controlled multicenter Food and Drug Administration investigational device exemption study of the ProDisc-C total disc replacement versus anterior discectomy and fusion for the treatment of 1-level symptomatic cervical disc disease. Spine J 2009;9:275-86.

36. Mummaneni PV, Burkus JK, Haid RW, Traynelis VC, Zdeblick TA. Clinical and radiographic analysis of cervical disc arthroplasty compared with allograft fusion: a randomized controlled clinical trial. J Neurosurg Spine 2007;6:198-209.

37. Anderson PA, Rouleau JP. Intervertebral disc arthroplasty. Spine (Phila Pa 1976) 2004;29:2779-86.

38. Pickett GE, Sekhon LH, Sears WR, Duggal N. Complications with cervical arthroplasty. J Neurosurg Spine 2006;4:98-105.

39. Sekhon LH. Cervical arthroplasty in the management of spondylotic myelopathy: 18-month results. Neurosurg Focus 2004;17:E8.

40. Pickett GE, Mitsis DK, Sekhon LH, Sears WR, Duggal N. Effects of a cervical disc prosthesis on segmental and cervical spine alignment. Neurosurg Focus 2004; 17:E5.

41. Johnson JP, Lauryssen C, Cambron HO, et al. Sagittal alignment and the Bryan cervical artificial disc. Neurosurg Focus 2004;17:E14.

42. Leung C, Casey AT, Goffin J, et al. Clinical significance of heterotopic ossification in cervical disc replacement: a prospective multicenter clinical trial. Neurosurgery 2005;57:759-63.

43. Chen J, Wang X, Bai W, Shen X, Yuan W. Prevalence of heterotopic ossification after cervical total disc arthroplasty: a meta-analysis. Eur Spine J 2012;21:67480.

44. Goffin J, Van Calenbergh F, van Loon J, et al. Intermediate follow-up after treatment of degenerative disc disease with the Bryan Cervical Disc Prosthesis: single-level and bi-level. Spine (Phila Pa 1976) 2003; 28:2673-8.

45. Cavanaugh DA, Nunley PD, Kerr EJ 3rd, Werner DJ, Jawahar A. Delayed hyper-reactivity to metal ions after cervical disc arthroplasty: a case report and literature review. Spine (Phila Pa 1976) 2009;34:E262-5.

46. Guyer RD, Shellock J, MacLennan B, et al. Early failure of metal-on-metal artificial disc prostheses associated with lymphocytic reaction: diagnosis and treatment experience in four cases. Spine (Phila $\mathrm{Pa}$
1976) 2011;36:E492-7.

47. Shim CS, Shin HD, Lee SH. Posterior avulsion fracture at adjacent vertebral body during cervical disc replacement with ProDisc-C: a case report. J Spinal Disord Tech 2007;20:468-72.

48. Datta JC, Janssen ME, Beckham R, Ponce C. Sagittal split fractures in multilevel cervical arthroplasty using a keeled prosthesis. J Spinal Disord Tech 2007;20:8992.

49. Tumialan LM, Gluf WM. Progressive vertebral body osteolysis after cervical disc arthroplasty. Spine (Phila Pa 1976) 2011;36:E973-8.

50. Buchowski JM, Sekhon LH, Yoon DH, et al. Adverse events of cervical arthroplasty. Tech Orthop 2010;25: 138-44.

51. Yi S, Shin DA, Kim KN, et al. The predisposing factors for the heterotopic ossification after cervical artificial disc replacement. Spine J 2013;13:1048-54.

52. Womack W, Leahy PD, Patel VV, Puttlitz CM. Finite element modeling of kinematic and load transmission alterations due to cervical intervertebral disc replacement. Spine (Phila Pa 1976) 2011;36:E1126-33.

53. Gornet MF, Taylor BA, Peloza JH, Schranck F. Late subsidence after cervical disc arthroplasty at one to four levels [Internet]. Aurora: International Society for the Advancement of Spine Surgery; [cited 2015 May 26]. Available from: http://www.isass.org/abstracts/isass12_oral_posters/isass12-409-Late-Subsidence-after-Cervical-Disc-Arthroplasty-at-One-toFour-Levels.html.

54. US Food and Drug Administration. Guidance for Industry and/or FDA staff: guidance document for the preparation of IDEs for spinal systems [Internet]. Silver Spring: US Food and Drug Administration; 2000 [cited 2015 Apr 21]. Available from: http://www.fda. gov/MedicalDevices/DeviceRegulationandGuidance/ GuidanceDocuments/ucm073771.htm.

55. Riew KD, Buchowski JM, Sasso R, Zdeblick T, Metcalf NH, Anderson PA. Cervical disc arthroplasty compared with arthrodesis for the treatment of myelopathy. J Bone Joint Surg Am 2008;90:2354-64.

56. Upadhyaya CD, Wu JC, Trost G, et al. Analysis of the three United States Food and Drug Administration investigational device exemption cervical arthroplasty trials. J Neurosurg Spine 2012;16:216-28.

57. Fan $\mathrm{H}$, Wu S, Wu Z, Wang Z, Guo Z. Implant failure of Bryan cervical disc due to broken polyurethane 
sheath: a case report. Spine (Phila Pa 1976) 2012;37: E814-6.

58. Nguyen NQ, Kafle D, Buchowski JM, et al. Ceramic fracture following cervical disc arthroplasty: a case report. J Bone Joint Surg Am 2011;93:e132(1-4).

59. Chen J, Wang X, Yuan W, Tang Y, Zhang Y, Wan M. Cervical myelopathy after cervical total disc arthroplasty: case report and literature review. Spine (Phila Pa 1976) 2012;37:E624-8.

60. Synthes Spine. ProDisc-C Removal System: instruments to assist with the removal of the ProDisc-C total disc replacement device [Internet]. Raynham: Synthes Spine; 2012 [cited 2012 Sep 10]. Available from: http://sites.synthes.com/MediaBin/US\%20 DATA/Product\%20Support\%20Materials/Technique\%20Guides/SPINE/SPTGProDisc-CRemovalJ10359A.pdf.

61. Medtronic. ACD instrument set: surgical technique shown with the Bryan cervical disc system [Internet]. Memphis: Medtronic Sofamor Danek; 2012 [cited 2012 Sep 10]. Available from: http://www.forma-
cionencirugia.com/archivos/BRYAN\%20ACD\%20 ST\%20NUEVA.pdf.

62. Tieder A. Mayo Clinic finds trends in knee replacement [Internet]. Rochester: Mayo Clinic; 2010 [cited 2012 Aug 30]. Available from: http://newsblog.mayoclinic.org/2010/03/08/mayo-clinic-finds-trends-inknee-replacement.

63. Anakwenze OA, Auerbach JD, Milby AH, Lonner BS, Balderston RA. Sagittal cervical alignment after cervical disc arthroplasty and anterior cervical discectomy and fusion: results of a prospective, randomized, controlled trial. Spine (Phila Pa 1976) 2009;34:20017.

64. Rand JA, Trousdale RT, Ilstrup DM, Harmsen WS. Factors affecting the durability of primary total knee prostheses. J Bone Joint Surg Am 2003;85:259-65.

65. Hacker FM, Babcock RM, Hacker RJ. Very late complications of cervical arthroplasty: results of 2 controlled randomized prospective studies from a single investigator site. Spine (Phila Pa 1976) 2013;38: 2223-6. 